\title{
THE OIL AND GAS SECTOR IN JANUARY-AUGUST 2013
}

\author{
Yu.Bobylev
}

In January-August 2013, the global oil market was characterized by the persistence of high oil prices. The 2013 annual volume of crude oil production in Russia will exceed 520 million tons, hitting record high since 1990. At the same time, according to statistics, the Russian oil industry is approaching its maximum production capacity. In order to compensate for the decline in oil production at the currently exploited oil fields, Russia will have to develop new oil fields in her remote areas with insufficient or nonexistent infrastructure as well as oil deposits on the continental shelf. Russia will also have to develop the currently ignored deposits of poor quality oil situated in the areas where oil production infrastructure already exists. In order to address that problem, Russia recently adopted Federal Law No 213-FZ, containing a number of corresponding fiscal measures designed to stimulate the development of hard-to-extract oil deposits. It is also planned that the Russian State Duma will soon adopt a draft law establishing a special preferential tax regime applicable to oil production from continental shelf deposits. It is hoped that these legal acts will encourage the development of the currently unexploited huge reserves of hardto-extract oil, thus helping Russia to maintain her present oil production level.

In January-August 2013, the global oil market was characterized by the persistence of high oil prices. Over the course of that period, the average price of Brent crude oil amounted to $\$ 107.6$ per barrel (Table 1$)$. The main factors behind the persistence of high oil prices were the rising demand for oil caused by world economic growth, led by the economies of China, India and other Asian countries; the sufficiently conservative policy of the OPEC; and also the geopolitical risks looming over the oil market. August saw a sharp rise in oil prices, caused by the escalation of tensions over Syria and the fears that the USA and other countries would militarily intervene in that country. In the final week of August, the price of Brent crude oil increased to \$115-117 per barrel. In the European market, prices for Russian natural gas were also impressively high. At the same time, they experienced a downward influence of the changing situation in the European natural gas market, caused by a considerable increase in natural gas supplies from other producers and a lower level of natural gas spot prices in comparison with prices for Gazprom's long-term contracts.

In January-July 2013, the volume of oil production in Russia grew by $0.7 \%$ on the corresponding period of last year (Table 2). As a result, it can be expected that the 2013 annual volume of crude oil production in Russia will exceed 520 million tons, hitting record high since 1990. At the same time, the growth rate of oil production rapidly declines, which can be explained in the main by the deterioration, for objective reasons, of extraction conditions. A considerable number of the currently functioning oil fields are decreasing their output, while the majority of the new oil fields are characterized by somewhat worse geographical and mining parameters, and so their development is associated with higher capital inputs and higher exploitation and transportation costs.

In the first half-year of 2013, Russian oil exports were characterized by the continuing decline in the volume of crude oil exports (which dropped by $2.5 \%$

Table 1

INTERNATIONAL PRICES OF OIL AND NATURAL GAS IN 2005-2013, USD/BARREL

\begin{tabular}{|c|c|c|c|c|c|c|}
\hline & 2005 & 2006 & 2007 & 2008 & 2009 & 2010 \\
\hline Price of Brent (UK), USD/barrel & 54.4 & 65.2 & 72.5 & 97.7 & 61.9 & 79.6 \\
\hline Price of Urals (Russia), USD/barrel & 50.8 & 61.2 & 69.4 & 94.5 & 61.0 & 78.3 \\
\hline \multirow[t]{2}{*}{$\begin{array}{l}\text { Price of Russian gas on the European } \\
\text { market, USD/1,000 } \mathrm{m}^{3}\end{array}$} & 212.9 & 295.7 & 293.1 & 473.0 & 318.8 & 296.0 \\
\hline & 2011 & 2012 & $\begin{array}{c}2013 \\
\text { Q1 }\end{array}$ & $\begin{array}{c}2013 \\
\text { Q2 }\end{array}$ & $\begin{array}{l}2013 \\
\text { July }\end{array}$ & \\
\hline Price of Brent (UK) & 111.0 & 112.0 & 112.9 & 103.0 & 108.0 & \\
\hline Price of Urals (Russia) & 109.1 & 110.3 & 110.8 & 102.1 & 107.9 & \\
\hline $\begin{array}{l}\text { Price of Russian gas on the European } \\
\text { market, USD/1,000 } \mathrm{m}^{3}\end{array}$ & 381.5 & 431.3 & 410.4 & 414.0 & 396.0 & \\
\hline
\end{tabular}

Source: IMF, OECD/IEA. 
PRODUCTION OF OIL, PETROLEUM PRODUCTS AND NATURAL GAS IN 2005-2013, AS A PERCENTAGE OF THE PREVIOUS YEAR

\begin{tabular}{|l|c|c|c|c|c|c|c|c|c|}
\hline & 2005 & 2006 & 2007 & 2008 & 2009 & 2010 & 2011 & 2012 & $\begin{array}{c}2013 \\
\text { January-July* }\end{array}$ \\
\hline Oil, including natural gas condensate & 102.2 & 102.1 & 102.1 & 99.3 & 101.2 & 102.1 & 100.8 & 101.3 & 100.7 \\
\hline Primary crude oil distillation & 106.2 & 105.7 & 103.8 & 103.2 & 99.6 & 105.5 & 103.3 & 104.9 & 102.7 \\
\hline Motor gasoline & 104.8 & 107.4 & 102.1 & 101.8 & 100.5 & 100.5 & 102.0 & 104.3 & 102.8 \\
\hline Diesel fuel & 108.5 & 107.0 & 103.4 & 104.1 & 97.7 & 104.2 & 100.3 & 98.7 & 103.9 \\
\hline Furnace fuel oil & 105.8 & 104.5 & 105.2 & 101.9 & 100.8 & 108.5 & 104.6 & 101.6 & 102.9 \\
\hline Natural gas & 100.5 & 102.4 & 99.2 & 101.7 & 87.9 & 111.4 & 102.9 & 97.7 & 99.6 \\
\hline
\end{tabular}

* As \% of January-July 2012.

Source: RF Federal State Statistics Service. RF Ministry of Energy.

on the first half-year of 2012) and by a simultaneous increase in the output and export of refined petroleum products (which rose by $10.3 \%$ on the corresponding period of 2012). Natural gas exports experienced no major fluctuations (Table 3). In the first half-year of 2013 , the share of fuel and energy products in the net volume of Russian exports amounted to $71.3 \%$, with the shares of crude oil and natural gas amounting to $33.1 \%$ and $12.6 \%$ respectively.

In the period under consideration, in response to the considerable deterioration, for objective reasons, of oil extraction conditions, Russia adopted Federal Law, of 23 July 2013, No 213-FZ 'On the Introduction of Alterations to Chapters 25 and 26 of the Second Part of the Tax Code of the Russian Federation and Article 3.1 of the Law of the Russian Federation "On the Customs Tariff"'. The Law contains a number of measures designed to stimulate the development of hard-toextract oil reserves, and introduces differentiated ad valorem mineral resources extraction tax rates for the regions, depending on the permeability of a particular reservoir, the size of the subsoil plot, and on the degree of depletion of the oil field.

Furthermore, the Law introduces a reduction factor, $K_{d}$, to be applied to the rate of Mineral Resources
Extraction Tax (MRET). The $K_{d}$ factor characterizes the difficulty of oil production. Depending on the characteristics of a specific deposit, the reduction factor $K_{d}$ will equal to:

- $\quad 0.8$ for oil extracted from deposits classed with the productive formations belonging to the Tyumen suite;

- $\quad 0.4$ for oil produced from a reservoir with permeability not exceeding $2 \times 10^{-3}$ micro square meters and thickness more than 10 meters;

- 0.2 for oil produced from a reservoir with permeability not exceeding $2 \times 10^{-3}$ micro square meters and thickness not exceeding 10 meters;

- 0 for oil extracted from deposits classed with the Bazhenov, Abalak, Khadum and Domanic productive formations.

- For oil produced from reservoirs with low permeability, the reduction factor $K_{d}$ should be used over the course of 120 tax periods (10 years) since 1 January of the year when the depletion of a particular reservoir exceeded $1 \%$.

For oil produced from reservoirs classed with the productive formations of the Tyumen suite and with the Bazhenov, Abalak, Khadum and Domanic productive formations, the reduction factor $K_{d}$ should be used

EXPORTS OF OIL, PETROLEUM PRODUCTS AND NATURAL GAS FROM RUSSIA IN 2005-2013, AS A PERCENTAGE OF THE PREVIOUS YEAR

\begin{tabular}{|c|c|c|c|c|c|c|c|c|c|}
\hline & 2005 & 2006 & 2007 & 2008 & 2009 & 2010 & 2011 & 2012 & $\begin{array}{c}2013 \\
\text { January-July* }\end{array}$ \\
\hline Oil, total & 98.4 & 98.0 & 104.0 & 94.0 & 101.8 & 101.2 & 97.6 & 98.2 & 97.5 \\
\hline $\begin{array}{l}\text { including: } \\
\text { to non-CIS countries }\end{array}$ & 99.1 & 98.0 & 104.8 & 92.6 & 102.9 & 106.1 & 95.7 & 98.7 & 97.1 \\
\hline Petroleum products, total & 117.9 & 106.3 & 108.0 & 105.0 & 105.3 & 106.2 & 98.5 & 104.4 & 110.3 \\
\hline $\begin{array}{l}\text { including: } \\
\text { to non-CIS countries }\end{array}$ & 119.1 & 104.5 & 107.6 & 102.0 & 107.1 & 109.6 & 94.6 & 100.8 & 118.7 \\
\hline Natural gas, total & 103.7 & 97.6 & 94.6 & 101.8 & 86.2 & 105.6 & 104.0 & 96.6 & 100.0 \\
\hline
\end{tabular}

* As \% of January-July 2012.

Source: RF Federal Statistics Service. 
over the course of 180 tax periods (15 years) since $1^{\text {st }}$ of January of the year when the depletion of a particular reservoir exceeded $1 \%$.

In order to determine the reduction factor $K_{d}$ in each specific case, one should use the indices of permeability and effective oil-bearing formation thickness relating to a particular reservoir, listed in the State Balance Report of Reserves of Commercial Minerals.

For purposes of tax administration, the Law establishes the following special requirement regarding the determination of the amounts of oil produced from the reservoirs where the reduction factor $K_{d}$ is used:

- The amount of produced oil should be determined for each of the wells functioning at a particular reservoir;

- The amount of produced well fluid should be measured, and its physic-chemical properties analyzed, at least 4 times per month.

Federal Law No 213-FZ also introduces an additional factor, $\mathrm{K}_{\mathrm{dv}}$ which characterizes the degree of depletion of a specific reservoir. When a reservoir is highly depleted (by more than $80 \%$ ), $\mathrm{K}_{\mathrm{dv}}$ becomes a reduction factor, calculated by a special formula.

Thus, in the future, the basic MRET rate (currently set at $\mathrm{Rb} 470$ per ton) may be applied with five coefficients characterizing major rent-forming factors. These coefficients are as follows:

- Factor $\mathrm{K}_{\mathrm{ts}}$, characterizing the movement of world oil prices (Table 4);

- Factor $\mathrm{K}_{\mathrm{v}^{\prime}}$ characterizing the depletion of a particular sub-soil plot;

- Factor $\mathrm{K}_{\mathrm{z}}$, characterizing the amount of reserves at a particular sub-soil plot;

- Factor $\mathrm{K}_{\mathrm{d}}$, characterizing the difficulty of oil production;

- Factor $\mathrm{K}_{\mathrm{dv}}$ characterizing the depletion of a particular reservoir.

Intended for tax calculations, the $\mathrm{K}_{\mathrm{ts}}$ factor makes it possible to take into account the current level of world oil prices, which, along with the volume of oil produc- tion, determines the producer's net revenue. This factor should be applied to oil produced from all oil fields without exception. The other coefficients are designed to decrease the tax load on the oil fields characterized by higher than normal development and operating costs (depleted and small oil fields, hard-to-extract reserves). Thus, from now on, the higher than normal development and operating costs, typical of such oil fields, will be taken into account due to the imposition of lower tax rates for hard-to-extract oil.

It should be noted that the productive formations for which the $K_{d}$ factor is set at 0 are similar to shale oil. Deposits of such oil are being actively developed in the USA. In Russia, such deposits remain undeveloped, although the Russian Federation has huge reserves of this oil, mainly in the areas where oil production infrastructure already exists, primarily in western Siberia.

Federal Law No 213-FZ also introduces a number of amendments to Law No 5003-1 'On the Customs Tariff'. In accordance with these amendments, oil produced from oil fields with more than $80 \%$ of reserves consisting of productive formations that belong to the Tyumen suite, should be included in the list of crude oil types entitled to reduced export duty rates calculated by special formulas.

At present, special formulas for calculating export duty rates for oil are applied to oil produced from oil fields in eastern Siberia (in the Sakha Republic (Yakutia), Irkutsk Oblast and Krasnoyarsk Krai), Nenets Autonomous Okrug, Yamalo-Nenets Autonomous Okrug north of the $65^{\text {th }}$ parallel north, and also in the Caspian Sea and on Russia's continental shelf.

It should be noted that Russia's continental shelf contains huge untapped reserves of oil. At present, the RF State Duma is considering a draft law designed to envisage the introduction of a preferential tax regime for the development of new offshore oil fields. It is planned that this tax regime will be based on a reduced ad valorem MRET rate differentiated by continental shelf zone (by category of a project's difficulty).

Table 4

RATES OF MRET APPLIED TO OIL PRODUCTION IN 2005-2013

\begin{tabular}{|c|c|c|c|c|c|c|c|c|c|}
\hline & 2005 & 2006 & 2007 & 2008 & 2009 & 2010 & 2011 & 2012 & 2013 \\
\hline Basic MRET rate on oil production, $\mathrm{Rb} /$ ton & 419 & 419 & 419 & 419 & 419 & 419 & 419 & 446 & 470 \\
\hline $\begin{array}{l}\text { Factor, characterizing move- } \\
\text { ment of world oil prices (Kts) }\end{array}$ & \multicolumn{4}{|c|}{ (Ts-9) x P/261 } & \multicolumn{5}{|c|}{$(T s-15) \times P / 261$} \\
\hline $\begin{array}{l}\text { Factor, characterizing depletion of } \\
\text { particular sub-soil plot (Kv) }\end{array}$ & \multicolumn{2}{|c|}{-} & \multicolumn{7}{|c|}{$3.8-3.5 \times \mathrm{N} / \mathrm{V}$} \\
\hline $\begin{array}{l}\text { Factor, characterizing amount of re- } \\
\text { serves at particular sub-soil plot (Kz) }\end{array}$ & \multicolumn{7}{|c|}{-} & \multicolumn{2}{|c|}{$\begin{array}{l}0.125 \times \mathrm{Vz} \\
+0.375\end{array}$} \\
\hline
\end{tabular}

Symbols: Ts - the average Urals crude oil price during a tax period, USD/barrel; $\mathrm{P}$ - the average official USD to Russian Ruble exchange rate, set by the RF CB; N - the cumulative volume of oil produced from a sub-soil plot; $\mathrm{V}$ - the initial recoverable reserves of Class $\mathrm{A}$, $\mathrm{B}$, $\mathrm{C} 1$ and C2 oils in a sub-soil plot; $\mathrm{Vz}$ - the initial recoverable reserves of oil in a sub-soil plot, millions of tons.

Source: RF Tax Code (as amended between 2005 and 2013). 
It is planned that new continental shelf projects are to be exempted from the exports duty on oil and property tax. It can be expected that this draft law will be adopted before the end of this year.

The latest statistics indicate that the Russian oil industry is approaching its maximum production capacity. Oil production in traditional oil producing areas is on the decline because of the depletion of their oil fields. In order to compensate for the dwindling of oil production from the oil fields currently in operation, emphasis should be made on developing the new oil fields situated in the areas with insufficient on nonexistent infrastructure, including deposits on the continental shelf, as well as on developing the currently ignored reserves of poor quality oil situated in the areas where oil production infrastructure already exists.

As the production costs of developing new oil fields and hard-to-extract oil reserves are very high, their development under the general tax regime is unprofitable. Therefore, the importance of the adoption of the above-mentioned legislative measures designed to reduce the tax burden of the companies developing hard-to-extract reserves and offshore oil fields cannot be underestimated. These legislative acts will encourage the development of the currently unexploited huge reserves of hard-to-extract oil, thus helping Russia to maintain her present oil production level. 